\title{
Maciej Soin
}

Lodz University of Technology

Faculty of Management and Production Engineering

Institute of Social Sciences and Management of Technologies

e-mail: maciej.soin@p.lodz.pl

\section{Philosophical difficulties of stakeholder theory*}

\begin{abstract}
Philosophical difficulties of stakeholder theory - which plays an important role in CSR and business ethics - are mainly connected to the questions of its status and justification. What sense does stakeholder theory have: descriptive, instrumental or normative? And if normative, why then should executives worry about multiple stakeholder demands?

It is well known that Freeman, one of the most important authors of stakeholder theory, deliberately disregarded these problems. In philosophical questions, he invoked Rorty's pragmatism that in his opinion effectively undermined the "positivistic" dichotomy between facts and values, science and ethics, and enabled stakeholder theory to be understood as both descriptive and normative.

The article presents some difficulties connected with this view, focusing on its dubious assumptions and unfavourable consequences. These assumptions contain a false dilemma, taken from Rorty, which states that knowledge follows either a rule of representation or a rule of solidarity. One of the unfavourable consequences is the conclusion that stakeholder theory may be true only if its followers are able to force the stakeholders to accept its truthfulness.

The main thesis of the article says that, because of pragmatic justification, stakeholder theory became a sort of arbitrary narration, which is unable to deal with its (empirical) misuses. However, a more traditional view on facts and values enables us to appreciate the descriptive advantages of the theory and to identify difficulties connected with its normative layer. From this point of view, the attempt at a pragmatic interpretation of stakeholder theory was a misunderstanding that should be withdrawn from circulation.
\end{abstract}

\footnotetext{
* The article is an updated version of the paper published in Polish in the Annales. Ethics in Economic Life, 19(3), 7-16.
} 
Keywords: stakeholder theory, pragmatism, facts and values, Freeman, Rorty

JEL Classification: A13, L21, M14

\section{The Problem}

The "stakeholder theory" is not an overly complicated concept, at least in basic ethical and business applications. As a reminder: let's take any enterprise P and let's call these economic entities, which somehow concerns the activities of this company with its stakeholders. Apart from owners, in the case of a joint-stock company-shareholders, there will be clients, employees, suppliers, etc. The basic content of stakeholder theory boils down to the claim that management $\mathrm{P}$ should be guided in its decisions not only by the interests of the owners but also by the interests of the other stakeholders. This means, among other things, that maximizing profits, and thus realizing the interests of the owners, is neither the only nor the main objective of the company's managers. The aim is balancing the interests of all the concerned groups. And regardless of whether the management of the enterprise is aware of it or not, these interests are considered to some extent, because assuming the elementary economic freedom of individual entities, otherwise it would not be able to cooperate at all.

However, problems start when we ask, to what extent should the company managers consider the needs and postulates of individual stakeholders? That means: how to understand the balancing of interests between, for example, the owners and clients of the company since these interests are at least in some way contradictory (for example, when it comes to the price of the purchased goods). And: why should these interests be considered, and not for example "guided by" the principle of profit maximization and hope that - as the liberal would like to believe - the "invisible hand of the market" will agree these actions with other, equally specific actions of other entrepreneurs and customers? The first of these issues - as a "difficulty in applying"-results from the very general nature of the concept and can be temporarily solved by its specification for individual cases. Therefore, it remains an empirical matter of practice. The second difficulty refers to the normative content of the stakeholder theory and asks for at least an outline of reasons that encourage its acceptance. We can, therefore, describe it as a philosophical "difficulty of justifying."

It is very characteristic of the contemporary state of philosophy, as well as social sciences, that Freeman, one of the main authors and propagators of the theory of stakeholders put a lot of effort to present this second difficulty as irrelevant. Although he initially referred to the authority of Kant and his imperative, in a mature version of his views he bound the theory of stakeholders to Rorty's philosophical pragmatism, which, in his opinion, effectively undermined the "positivist" dichotomy between facts and values, as well as between science and ethics. 
By doing so - at least according to Freeman — he made it possible to recognize the stakeholder theory as both a descriptive and a normative concept, and thus- to recognize the said problem as poorly placed.

The only question is whether such a resolution does not generate new difficulties related to the dubious assumptions and consequences of the adopted perspective. In our deliberations, let us take a closer look at Freeman's and his colleagues' arguments, aiming to justify the thesis that the association of the theory of stakeholders with philosophical neo-pragmatism brought more harm than good. It cannot be defended either practically or theoretically.

Although we will mainly deal with the normative layer of stakeholder theory and its use in business ethics, apart from most of the complications associated with Freeman's position, we will see that in his texts (neo) pragmatic interpretation of the stakeholder theory has been carried out so firmly that, the purpose of the criticism is quite clearly.

\section{Two versions of the justification of stakeholder theory}

As was said, Freeman's views on the philosophical basis of the stakeholder theory were subject to significant evolution, and the first version of the "difficulty of justification"-formulated in the famous article by Evan and Freeman in 1983appealed to the imperative of Kant and only casually mentioned his more recent studies. The stakeholder theory was there presented as a kind of revision of the enterprise theory in the "Kantian spirit", expressing first of all the principle that each group of stakeholders "has the right to be treated as a goal in itself, and not only as a means to achieve a goal" (Evan \& Freeman, 1997, p. 187). If the question was: "in whose interest should the company operate?", the answer emphasized the need to balance the interests of particular groups resulting primarily from the application of the Kantian imperative to determine the company's objectives. It was, therefore, a typical normative concept, extending managers' obligations towards owners (shareholders), by appropriate definitions, and thereforespeaking Wittgenstein's jargon-doing it with grammatical movements. ${ }^{1}$

Although the arguments of Evan and Freeman also used practical suggestions (the need to balance the interests of individual groups is also important from the point of view of the company's survival), as well as concepts characteristic of consequences ethics (e.g. the concept of unintended effects), the absolute priority was given to the ethics of duty. The main point of justification was limiting the possibilities of actions resulting from the right of ownership by denying the company and its managers the right to infringe the guiding principle of the autotelicity of the stakeholders. The duty to comply with it was the undisputed assumption of

\footnotetext{
${ }^{1}$ The version of the justifications was moreover, and as testified by Phillips, Freeman and Wicks in the article What Stakeholder Theory Is Not (2003, p. 481) alongside Kantianism Freeman, his collaborators and other supporters of the "stakeholder theory" also referred to such different concepts as the idea of the common good, feminist ethics, risk concepts, property rights, social agreements etc.
} 
the authors, who, on the one hand, stipulated that they did not intend to treat such formulas as "absolute truths", but on the other hand they argued that each stakeholder theory must be in line with the principles derived from Kant's imperative: limited company rights and responsibility for the effects of its operation (cf. Evan $\&$ Freeman, 1997, p. 193). ${ }^{2}$ From this point of view, the consequences of the actions, including the unintentional ones, are only valid as long as the company has to ensure their compliance with the mentioned principles.

Why, however, must it? On this issue, Evan and Freeman could only repeat that according to the stakeholder theory, the company should be managed for the benefit of stakeholders, and its managers must represent the interests of all their groups (cf. Evan \& Freeman, 1997, p. 200). Of course, the compliance of the postulated management principles with the stakeholder theory is no justification for the stakeholder theory, because it assumes what would possibly support. And no wonder, since - as we remember from the lesson of Hare, or actually Wittgenstein - ethical argumentation, like any argument, reaches its end with the articulation of its main principles (cf. Hare, 1952, p. 32 et seqq.; Wittgenstein, 1972, item 217 et seqq.). If the Kantian imperative does not justify what defines the theory of stakeholders, then in response to the objections resulting from the different understanding of the purpose of the enterprise (e.g. known Friedman arguments) we can only repeat the questioned explanation. Only that in a dispute about the purpose of economic activity, as in any case in which two opposing principles meet, or two competing systems of postulates, one side presents itself to the other as a kind of foolishness or dissociation (cf. Wittgenstein, 2001, item 611).

Perhaps this is the reason why Freeman in his subsequent works changed both the collaborator and the way of presenting the theory of stakeholders. The mature resolution of the problem of its justification, presented in the 1998 article by Wicks and Freeman (1998), referred no longer to Kant but to the "new pragmatism". Although the argument contained in this article referred to the whole of organizational research, in a later statement of achievements it obtained the status of developing the principles of "pragmatism for theoreticians of the stakeholder" (cf. Freeman, Harrison, Hicks, Parmar \& de Colle, 2010, p. 72 et seqq.). ${ }^{3}$ According to the thesis of Wicks and Freeman, a position that revolutionizes research on organizations because it avoids epistemological opposition marginalizing their ethical dimension. It allows to focus organizational research on their "practical relevance", subordinated - according to the authors' statement — to making people live better.

Pragmatism, or "new pragmatism", of which reported authors are concerned, is associated above all with - not only in the American humanities - Richard Rorty's over-influential position. It builds its identity mainly in opposition to positivism and neo-positivism. Wicks and Freeman enumerate the whole set of allegedly

\footnotetext{
${ }^{2}$ The emphasis on the compliance of actions with the rules requires doubting whether the referred concept has a Kantian character. As it is known, according to Kant, compliance with the obligation alone is not enough to consider action as ethical. Intentions are decisive. Cf., for example, Höffe, 1995, p. 178.

${ }^{3}$ The repetition of thesis from the article from 1998 in the "canonical" presentation of the stakeholder theory from 2010 proves that we are dealing with its current and still sustained version.
} 
false alternatives characteristic of this apparently outdated way of thinking, with the advantage of the new approach being to avoid them $\left(1998\right.$, p. 125 et seqq) ${ }^{4}$ This applies to issues as basic as:

(1) opposition between discovery and creation (finding/making); in this case, Wicks and Freeman accuse positivism above all persistently holding on to objectivity and disregarding the processes of social construction of reality;

(2) opposition between the description and the obligation (describing/prescribing), where the result of positivist attachment to the idea of an impartial description of facts is the exclusion of the most interesting questions (such as "what I should do?") in the field of scientific reflection;

(3) opposition between science and non-science (science/non-science), in which the negative effect of positivist fixation on the point of the method is to deprive the value of other types of research, not based on strict rules of justification of theorems (e.g. a humanistic type, including an ethical one).

The source of errors that Wicks and Freeman consider to be avoided due to the pragmatic perspective, is the attachment to the positivist idea of a non-valuing science centered on discovering an allegedly objective truth. This does not mean, as the authors argue, that pragmatism is to be a simple reversal of positivism in which "everything goes". According to their declaration, it is rather about blurring the boundaries between the members of the mentioned opposition, hence between finding and making, describing and prescribing, and finally between science and non-science. According to the more positive suggestions of Wicks and Freeman, the reality is not an illusion, it should not be attributed to its objective nature. The idea of "right opinions" about reality, based on its purely current view, is a myth because every inquiry is essentially an interpretation or narration. If science is a language game, or more strictly - one of many language games, equal ways of telling stories about the ambiguous reality, it does not take priority even in what is usually considered its domain, namely in the field of science. In short, along with the (neo) pragmatic casing, the stakeholder theory is equipped with a standard set of postmodernist ways to depreciate objectivity, cognition and truth. ${ }^{5}$

What does this mean for stakeholder theory? First, the fact that for a credible explanation of the ethical obligations of managers, becomes a matter of agreement on acceptable rules of economic activity, to be reached between stakeholders. And, moreover, that along with all the alternative visions of management theory and the enterprise is presented as a kind of "pragmatic experimentation", that is, unrestrained testing of new organizational ideas, or "alternative ways of life" -

\footnotetext{
${ }^{4}$ Incidentally, a closer look at the writings of at least some of the "positivists" could show to what extent their picture, drawn up by Wicks and Freeman, is based on philosophical stereotypes. Carnap, for example, in his ontological views was much closer to postmodernism than, say, classical metaphysics. Cf. Soin, 2016a.

${ }^{5}$ When asked "is Rorty's neo-pragmatism a variant of the postmodernist campaign against the great narratives?". The answer must be yes. Cf. Szahaj, 2002, p. 188 et seqq.
} 
created to "better realize human aspirations". In line with Wicks and Freeman's general message to scientists dealing with organizations who instead of imitating reality, or looking for the hidden basis of phenomena, should run the creative power of the imagination (1998, p. 130 et seqq.; cf. Freeman et al., 2010, p. 73). Although these authors repeatedly assure that the acceptance of pragmatism does not entail the abandonment of current research standards we know that: instead of conducting esoteric and irrelevant discussions "that do not make a difference", the academics should primarily contribute to the progress contributing to the improvement of the quality of life (cf. Wicks \& Freeman, 1998, p. 136).

\section{Critical remarks}

Both the early, "Kantian" version of the justification of the stakeholder theory, as well as its later, pragmatic variant, raise important doubts, which we will present in a very short form, not going to exhausting the doubtful places in the arguments of Freeman and his associates. We will focus on the pragmatic version of the problem as more sophisticated than the "Kantian" version. It is enough to say about the latter that it cannot justify its normativity other than by appealing to authority, in addition, misunderstood, since - as has been said - the assignment of a simple ethical duty to Kant neglects the basic role of intentions in the constitution of the ethical dimension.

On the other hand, the pragmatic version can be said with a high probability that at the source of its most questionable points lies the erroneous interpretation of the views of late-Wittgenstein, widespread among others by Rorty. ${ }^{6}$ In this interpretation, the discussion about language games is treated as a convincing argument for relativism that invalidates the classic or correspondence concept of truth. Meanwhile, one should distinguish between language games in which it comes to cognition and which are equipped with mechanisms for adopting rules to their subjects, from language games in which there is something other than the growth of knowledge (religion, art, teaching, playing, etc.). And also, to notice that the situation of such abstract sciences about necessity as mathematics or logic is quite different from sciences based on empirical evidence, especially those dealing with natural types, e.g., botany or zoology. And that there is another case of management sciences that operate on the purposerational level of analysis, that is, they do not discuss goals, but the means to achieve those goals. Using Wittgenstein's stand to oppose old-fashioned positivist objectivity and (post) modern "philosophy of hope" is an error, at best, based in misunderstanding. The interpretative and factual error of Rorty and other postmodernists is in their attempt to fit different things into one pattern.

\footnotetext{
${ }^{6} \mathrm{Cf}$. Soin (2008), where one can find a textual justification for the non-postmodernist interpretation of the evolution of Wittgenstein's views.
} 


\subsection{The ambiguity of "better life" and "usability"}

So much for the overall perspective of criticism of linking the theory of stakeholders with neo-pragmatic postmodernism. More specific, perhaps the most abusive misuse of both Freeman and his patrons is the way of using the slogan of "better life" as the only proper goal of philosophical and scientific activity (and the purpose of giving sense to the teachings about the organization), as if it was a well-defined and noncontroversial idea. Meanwhile, the highly disputable character of what different people will be called "better life" and "striving for it" is not only the basic fact, which omission leads to generals, but also the main problem, however, requires a more careful approach to the facts and values. ${ }^{7}$ In part, Wicks and Freeman also had to admit it, stating that pragmatism in their notion is not identical with utilitarianism, because talking about usability refers to the question about its evaluation criteria, diversified in a pluralistic society, and therefore to the question of whose values will be used as criteria for assessing organizational progress (1998, p. 129). However, this means that, contrary to the assurances of Wicks and Freeman, the concept of utility cannot fulfil the role of the assessment criterion. It is as diverse as the value systems that lie behind it and that can serve its opposing specifications.

\subsection{The formal nature of the thesis about the construction of reality}

It should be noted, moreover, that neither the constructivist thesis about social creation of reality nor the classics of pragmatism about the processes of making sense of its elements are applicable to any justification of stakeholder theory, for the simple reason that any content can be adapted to them, regardless of its political, ethical or unethical connections. This is because the mechanisms of "sensemaking" indicated by the sociological classics of pragmatism are basically purely formal, referring mainly to the way in which meaning is given. And no wonder, since every idea can be the subject of dissemination, objectification, socialization and internalization, equally democratic, or authoritarian, both conservative and liberal. However, if pragmatism is unsuitable for justification, then its usefulness for answering the most practical question summoned by Freeman, namely: what we should do?-is zero. More so when it comes to an equally practical question: which ideas should be disseminated and whose ideas we are to teach.

\subsection{Nihilist consequences and internal contradiction}

Of course, the justification of the normative actions of the stakeholder theory was not the goal of the authors who were discussing Rorty's intention to annul the problem of justification as a relic of "foundationalism." If every allegedly purely

\footnotetext{
${ }^{7}$ Cf. Soin (2013) where the results of analytical investigations on the relationship of facts and values are discussed, emphasizing the importance of social homogeneity in this matter.

${ }^{8}$ Cf., for example, Rorty (1996), where already in the introduction we will find out that the truth should be replaced by freedom, although it cannot be justified because even the conviction that cruelty is a terrible thing cannot be justified.
} 
descriptive theory is essentially normative in nature, then demanding justification from a concept like the theory of stakeholders is in the eyes of a pragmatic postmodernist an unjustified exaggeration, resulting from attachment to the oldfashioned idea of objectivity. Only then it turns out that the theorist's main problem - also in the field of management science - is not patient collecting evidence for the claims formulated within it but obtaining such an influence on his subject to shape it in accordance with these claims. For if what is considered true is true, instead of arguing for a thesis, it must be ensured that enough people recognize it as truth. In short, according to the logic of the social construction of reality instead of matching the theory to the object, the object should be changed according to the suggestive postulates of theory. This is an otherwise modern version of fullblooded Bolshevism, consistent with the Leninist formula of reading the classics of German idealism, for which — as you can recall—Lenin was criticized by the soberer communists as a voluntarist. This formula is also inherited from Rorty by Wicks and Freeman, which is indicated, inter alia, by the enthusiasm with which they praise unhampered "pragmatic experimentation", thus introducing new organizational and definition solutions primarily because they are new. But because the authors at the same time argue that they do not accept extreme relativism in the style of "everything goes" and do not give up the standards of science, then the philosophically expanded version of the stakeholder theory, in addition to cognitive nihilism, is characterized by an internal contradiction.

\subsection{Alleged overcoming false alternatives}

Therefore, contrary to what Wicks and Freeman claimed, and what the authors of the sum of achievements of the theory of stakeholders repeated, there is no qualitative difference between neo-pragmatism and relativistic anti-positivism. On the contrary, if the criterion of usability is not a criterion because its content depends on the value-based system and changes from case to case, then a new kind of ethical inquiry about the organization - in an unrestrained way of using the imagination-remains its purely subjective creation. At most, along with a pragmatic elaboration of the stakeholder theory, a false alternative inherited from Rorty comes to the front. This alternative says that cognition and reasoning, knowledge and learning can either be an absolute system, completely imitating reality and founded on unshakable foundations, or there is no such thing at all. And because a lot can be said about our cognitive achievements, but not that they form an absolute knowledge system (no matter how well some of our knowledge is justified), then the postmodernist verdict is: in fact, science is no different from magic and we should not recognize its cognitive superiority. Quite close to the slogans like "everyone has their own truth" and other anti-rational beliefs, as if analyzing these matters could only be operated with an unrealizable ideal. ${ }^{9}$

\footnotetext{
${ }^{9}$ Rorty's alternative belongs to the typical cases analyzed by Wittgenstein as errors resulting from the use of excessive generalizations. Cf., for example, Soin, 2014.
} 


\section{Conclusions}

In conclusion, we can say that because of a marriage with (neo) pragmatism, the stakeholder theory has become a kind of arbitrary narrative focused on selfpromotion, that is, the self-aware practice of spreading beliefs about yourself and by the way on your subject. Therefore - as you can argue - this connection does not work either theoretically or practically. It does not work theoretically, because apart from slogans about a better life, it does not have any evidence for its grammatical-normative content. It does not work empirically, because it cannot cope with the notorious abuse of the rhetoric of stakeholders as a smokescreen for activities carried out in a purely selfish interest. ${ }^{10}$ On the one hand, the general nature of the theory contributes to this, but on the other, it is associated with a perspective for which, in principle, such issues are not important. That is why an attempt to pragmatically interpret the theory of stakeholders should be considered a misunderstanding, which should be withdrawn as soon as possible. Only then - thanks to the traditional distinction between facts and values-we will be able to appreciate the descriptive qualities of the theory and identify the difficulties associated with its normative layer.

\section{References}

Evan, W. M., \& Freeman, R. E. (1997). Spółka i osoby żywotnie zainteresowane. Kapitalizm kantowski. In L. V. Ryan, \& J. Sójka (Eds.), Etyka biznesu. Z klasyki wspótczesnej myśli amerykańskiej (E. Dratwa, Trans.). Poznań: Wydawnictwo "W drodze" [(1983). A stakeholder theory of the modern corporation: Kantian capitalism. In T. L. Beauchamp, \& N. E. Bowie (Eds.), Ethical theory and business. New York: Prentice Hall, Englewood Cliffs].

Freeman, R. E., Harrison, J., Hicks, A., Parmar, B., \& de Colle, S. (2010). Stakeholder theory. The state of the art. Cambridge: Cambridge University Press.

Hare, R. M. (1952). The language of morals. Oxford: Oxford University Press.

Höffe, O. (1995). Immanuel Kant. (A. M. Kaniowski, Trans.). Warsaw: Wydawnictwo Naukowe PWN.

Phillips, R., Freeman, R. E., \& Wicks, A. C. (2003). What stakeholder theory is not. Business Ethics Quarterly, 13(4), 479-502.

Rorty, R. (1996). Contingency, irony, and solidarity (W. J. Popowski, Trans.). Warsaw: Wydawnictwo Spacja.

Soin, M. (2008). W kwestii prawdy. Wittgenstein i filozofia analityczna. Warsaw: Wydawnictwo Instytutu Filozofii i Socjologii PAN.

\footnotetext{
${ }^{10}$ We cannot develop this issue here, which, however, is an equally important issue, as incompatible with declarations of use, made of the slogans of Corporate Social Responsibility. A good example where these problems can be considered is the issue of Internet governance, in which dominant entities refer to stakeholder theory. Cf. Soin, 2016c.
} 
Soin, M. (2013). Wartość i fakt. Etyczne i socjologiczne zastosowania filozofii lingwistycznej. Warsaw: Wydawnictwo Instytutu Filozofii i Socjologii PAN.

Soin, M. (2014). O sporze Poppera z Wittgensteinem. Przeglad Filozoficzny - Nowa Seria, $4,125-138$.

Soin, M. (2016a). Deflacjonizm. In J. Hołówka, \& B. Dziobkowski (Eds.), Panorama wspólczesnej filozofii. Warsaw: Wydawnictwo Naukowe PWN.

Soin, M. (2016b). Filozoficzne trudności teorii interesariuszy. Annales. Ethics in Economic Life, 19(3), 7-16.

Soin, M. (2016c). Interesariusze internetu. Prakseologia, 158(1), 213-240.

Szahaj, A. (2002). Ironia i miłość. Neopragmatyzm Richarda Rorty'ego w kontekście sporu o postmodernizm. Wrocław: Wydawnictwo Uniwersytetu Wrocławskiego.

Wicks, A. C., \& Freeman, R. E. (1998). Organization Studies and the New Pragmatism: Positivism, Anti-positivism, and the Search for Ethics. Organization Science, 9(2), 123-140.

Wittgenstein, L. (1972). Philosophical Investigations. Warsaw: Państwowe Wydawnictwo Naukowe.

Wittgenstein, L. (2001). On Certainty. Warsaw: Wydawnictwo KR. 